UDK: 81 '38

DOI: $10.33669 / \mathrm{KJ} 2021-32-06$

primljeno / received: 7.7.2021.

prihvaćeno / accepted: 13. 12.2021.
Pregledni naučni rad

\section{Haris Ćatović}

Univerzitet u Sarajevu - Institut za jezik

Hasana Kikića 12, Sarajevo

Bosna i Hercegovina

haris.catovic@izj.unsa.ba

\title{
Stilogenost vremenski raslojene leksike u Rječniku bosanskog jezika autora Dževada Jahića
}

Sažetak: U radu se na početku govori o nekim teorijskim aspektima funkcionalno-stilskog raslojavanja leksike, pri čemu se naglasak stavlja na govorni jezik i njegov utjecaj na standardni jezik u smislu generiranja novih stilskih vrijednosti. Govorni jezik pripada razgovornom stilu, pa s obzirom na to ima veliki potencijal u stvaranju konotativnog značenja riječi, njegove granice nisu jasno postavljene, a u komunikacijskom činu gotovo svaka riječ može se podvrgnuti semantičkoj modifikaciji, usljed čega može poprimiti posebne semantičke ili stilske nijanse. Stilsko nijansiranje leksike svoje utemeljenje pronalazi u popunjavanju komunikativnih praznina, kojima se, različitom upotrebom u okviru različitih konteksta, mogu aktivirati željeni efekti u nastojanju da se dobije nijansa značenja koja je primjerena okolnostima u kojima nastaje. Nadalje se u radu posebna pažnja posvećuje stilogenim vrijednostima vremenski raslojene leksike, odnosno pasivne leksike u Rječniku bosanskog jezika autora Dževada Jahića. Korištenjem leksike koja je u savremenom smislu izašla iz upotrebe u tekstu do izražaja dolazi njena funkcionalna orijentacija, koja s obzirom na kontekst u kojem se koristi može imati različit stepen stilske ekspresivnosti. Razmatra se, dakle, stilski karakter leksema s kvalifikatorom arhaizma, historicizma, povijesne i zastarjele leksike uzimajući u obzir primjere ekscerpirane iz građe koji su dati uz pojedinu natuknicu. Na osnovu provedene analize, utvrdili smo da stilska funkcija pasivne leksike nije ništa drugo doli izražavanje historijske izvornosti nekog događaja. Korištenje pojmova iz nekadašnje ere bitisanja pomaže piscima da njihovo književno djelo dobije na istinitijem i uvjerljivijem slikanju određenog perioda, prenoseći na taj način historijsko-društvene i kulturne obrasce te materijalnu kulturu nekog podneblja.

Ključne riječi: jezičko raslojavanje, stilogenost, razgovorni stil, konotativnost, arhaizam, historicizam, povijesna leksika, zastarjela leksika 


\section{O nekim aspektima funkcionalno-stilskog raslojavanja leksike}

Jezik je složen sistem jezičkih resursa koji usklađeni po određenim načelima omogućavaju da kao cjelina prirodno funkcionira. U takvom složenom sistemu svoje lingvističko mjesto pronašao je stilski nivo. Lingvistička stilistika kao nauka do danas je postigla značajne rezultate, a svojim uvidima i metodološkim postupcima definirala konkretne teorijske obrasce te razradila terminološki instrumentarij kojim se služi prilikom pristupa književnom tekstu ili jeziku uopće. Istražujući načine na koji funkcioniraju jezička sredstva, dala je odgovore na upotrebu jezika u različitim društvenim kontekstima. Za te potrebe izvršena je diferencijacija stilova jednog jezika i razlika u njihovim ostvarenjima određena je činjenicom da postoje objektivni parametri na osnovu kojih se vrši njihovo klasificiranje, a utvrđeni su selekcijom i načinom upotrebe jezičkih sredstava. To znači da postoji dobro uvriježena shema u kombiniranju jezičkih sredstava specifična za određeni funkcionalni stil. Tako je npr. književnoumjetnički stil određen individualnim jezičkim izborom, odnosno slobodnijim jezičkim izrazom, dok je za administrativno-poslovni funkcionalni stil uglavnom izvršena selekcija jezičkih sredstava te joj je određen način na koji se upotrebljava, s težnjom da se u nekoj ljudskoj djelatnosti profesionalna korespondencija svede na jedinstvenu normu ili oblik. Stoga je jasno da lingvistička stilistika predstavlja vezivno tkivo na relaciji jezik - društvo. Dakle, ona se ne može proučavati izolirano od društva i razvoja pojedinoga književnog jezika općenito.

Oblikovanje književnog jezika relativno je dovršen fenomen, vremenski uvjetovan jer na njegov razvoj neprekidno utječe govorni jezik. Milka Ivić (1990: 96-107) ukazuje na značaj govornog jezika "u kontekstu njegovog utjecaja na standardni jezik, što se pri normiranju ne smije zanemariti". To se ne smije gubiti iz vida, jer govorni jezik i njegovi sadržaji postepenim djelovanjem vrše utjecaj na određeni nivo jezičke strukture, pa npr. pojedino kolokvijalno značenje u prvoj fazi koegzistira sa izvornim značenjem lekseme, a u drugoj fazi može potisnuti izvorno značenje lekseme, što u prvom redu zavisi od subjektivnog odnosa izvornog govornika prema novom značenju koje je proizvedeno, 
a koje doživljava kao manje formalno, razumljivije i uobičajenije u razgovornom stilu. To je razumljivo, jer neformalna, opuštena atmosfera omogućava osobama da lakše iskazuju svoje lične kvalitete, preferencije pa i osjećaje, što nikako nije karakteristično za komunikaciju koja se odvija u nekim službenim odnosima. Klajn (1998: 139), govoreći o kriterijima semantičkog normiranja, navodi sličnu konstataciju: “u toku jezičkog razvoja mogu se javiti nova značenja, a stara mogu biti potisnuta iz upotrebe". U tom smislu, razgovorni stil, odnosno govorni jezik je riznica iz koje nastaje emocionalno bogatiji i stilski obojen govor. Na osnovu toga, razgovorni stil ima veliki potencijal u stvaranju konotativnog značenja riječi jer njegove granice nisu jasno postavljene, a u komunikacijskom činu gotovo svaka riječ može se podvrgnuti semantičkoj modifikaciji, usljed čega može poprimiti posebne semantičke ili stilske nijanse. Ristić (1997: 51) smatra da "ostvarivanje različitih stilskih efekata pomoću ekspresivnih jedinica bilo kog jezičkog nivoa nije primarna karakteristika jezika književnoumetničkih tekstova nego jezika svakodnevne komunikacije - razgovornog jezika”.

Stilistika govora jedan je od predmeta proučavanja koju Viktor Vinogradov (1971: 299-305) u svojim stilističkim opservacijama smatra generatorom novih stilskih kategorija jer ona "utvrđuje i nove stilske kategorije, nijanse stilskih uporaba te nove tipove stilskih struktura prema njihovu govornome ostvarenju".

Nadalje, konotativnost ujedno predstavlja prekid s onim autentičnim, osnovnim, izvornim, objektivnim značenjem riječi, istovremeno isključujući objektivnu percepciju svega onoga što jeste, te uključujući posebnu izražajnost koja je potaknuta pristrasnošću, asocijativnošću, ekspresivnošću. Na koji će način biti izražena stilogenost zavisi od konteksta koji je profilira, a s obzirom na to da može nastati u različitim kontekstima, može projicirati veliki broj estetskih, odnosno stilogenih mogućnosti.

Vrlo je važno ukazati na to da granice među određenim stilističkim kategorijama nisu čvrsto zacrtane, često se prepliće jedna stilistička kategorija s drugom, dolazi do njihova miješanja pa čak i zamjene, što je rezultat ekstralingvističkih faktora, odnosno u ovom slučaju subjektivnog 
osjećaja ili pristupa autora rječnika. Sličnu konstataciju iznosi i Menac (1998: 261-262) navodeći da:

Stilistička kvalifikacija je osobito podložna različitim pristupima, pa su i konkretna rješenja različitih leksikografa često različita. Lingvistička stilistika, kao mlada znanost, ne može uvijek ponuditi gotova i provjerena rješenja kao što ih nude npr. fonologija, morfologija i tvorba riječi, a leksikografija ta rješenja bez daljnjega prihvaća. Na stilističkoj razini, iako je teoretski mnogo toga i riješeno, u primjeni poneka pitanja ostaju otvorena, pa se i stilističkim kvalifikacijama često pristupa subjektivnije nego drugim elementima leksikografske obrade.

Dakle, proučavanjem različitih leksikografskih ostvarenja, uočeno je da postoji problem koji stoji na putu stvaranja optimalnog modela stilske diferencijacije u opisu leksičkog materijala, a to je upravo postojanje različitih gledišta na samu definiciju stilskog sloja i stilsko nijansiranje. U sistemu kategorizacije stilogenosti trebalo bi nastojati odrediti jasne kriterije, ukazujući na razlike u funkcionalno-stilskom koloriranju, što znači da bi težište u tom nastojanju, s jedne strane, trebalo prebaciti na upotrebu pojedinih leksičkih jedinica, a s druge strane na ekspresivno-emocionalnu obojenost, ukazujući na izražajna svojstva određenog leksema. ${ }^{1}$ Po našem mišljenju, glavni uzrok tome može se tražiti u nedovoljno razrađenom sistemu u okvirima već postojećih teorija stilova, što na neki način onemogućava pojednostavljivanje stilskih podgrupa, odnosno kvalifikatora kojima se određuje upotrebna vrijednost riječi. Iako su se u svojim studijama mnogi teoretičari približavali optimalnom modelu, činjenica je da:

Lingvistička literatura ne pruža uvek sasvim precizne definicije pojmova vezanih za nestandardnu upotrebu jezika (ovde prevashodno mislimo na kolokvijalizme, žargonizme, argotizme, elemente slenga i šatrovački govor), koje bi omogućile potpuno jasno razgraničenje onih leksički markiranih elemenata, stilskih postupaka i tehnika (poput kolokvijalizacije ili žargonizacije) (Durbaba 2015: 211).

1 "Objektivno predstavljanje i precizno markiranje leksičkih jedinica jednog jezika, a ne njihovo izostavljanje, jeste način da akademijski rečnici odgovore i svom zadatku valjanog leksičkog normiranja." (Ristić 1995: 238). 
Čini se da je gotovo nemoguće utvrditi najjasnije granice u stilskom diferenciranju leksike, ${ }^{2}$ jer je ona rezultat konotacije koja je uvijek subjektivna pojava, određena govornikovom intencijom, njegovim odnosom prema onome o kome ili čemu se očituje. ${ }^{3}$ Muratagić-Tuna (1992: 9) u tom kontekstu kaže da "jezički izraz ima za cilj neposredno izražavanje ličnog odnosa prema onome o čemu se govori. To je ekspresivna, emotivna, afektivna funkcija jezika."

$\mathrm{Na}$ kraju, svaki govornik ima vlastito jezičko iskustvo profilirano njegovom obrazovnom ili kulturnom orijentacijom, njegovim društvenim ili ekonomskim statusom, a koja je naravno odraz trenutka u kojem govori pa zato treba izučavati jezičke sisteme i stilove svake epohe i razumijevanje društveno-ideološkog smisla jezika, kao i opšte duhovne klime toga doba (Vuković 2000: 130). Ako uzmemo ovakav Vukovićev pristup, vidljivo je da se oslanja na teoriju kognitivizma jer, iako znamo da su "kognitivni procesi koje ljudi koriste univerzalni, njihove primjene nisu, što zavisi i od razlika u stepenu elaboracije, konkretizacije, iskustvenom fokusu, spremnijem korišćenju metonimije, ili metafore itd.” (Kövecses 2005: 246), jer prema kognitivnolingvističkoj teoriji, kako objašnjava Lakoff (1987: 377), u situacijama u kojima doživljava određenu emociju, čovjek ne samo da "osjeća ono što osjeća" već i istovremeno uključuje svoje razumijevanje onoga što osjeća. Ristić (2002: 90) također navodi da je "za predstavljanje konotativnog značenja ekspresivne leksike u deskriptivnoj leksikografiji naročito važan zahtev kognitivne teorije da se u strukturi značenja moraju predstaviti svi tipovi značenja”. Nadalje Ristić (2006: 218) navodi da je “za tumačenje ekspresivne leksike značajno i to da se u kognitivnom pristupu leksičko značenje razmatra u vezi sa situativnošću, sa frejmom određene situacije u kome se data reč javlja ili u okviru šireg frejma ili da označi sam frejm uključen u određenu situaciju”.

2 Bugarski je analizirajući Rječnik Matice srpske i hrvatske i Rječnik srpskohrvatskog književnog i narodnog jezika ustanovio da leksikografski opisi nisu dovoljno precizni i informativni, pa stoga nisu ni relevantni za neka dublja istraživanja (Bugarski 2006: 23-24).

3 Procesi u jezičkom raslojavanju ispoljavaju se ne samo u gubljenju granica između postojećih stilova nego i u stvaranju novih varijeteta, u neprekidnom pregrupisanju njihovih idioma i u promjenama mesta na skali prestižnosti. (Ristić 2006: 26) 
Po svemu sudeći, primjena kognitivnih teorija u stilskom diferenciranju leksike predstavlja izrazito složen model proučavanja, ali jako koristan jer nudi integralan pristup, uključujući širok dijapazon pojava i iskustava s kojima se govornik određenog jezika u toku svog života susreće, što na kraju utječe i na oblikovanje jezičkoga znanja i njegove upotrebe. Na osnovu svega dosad rečenoga može se kazati da stilsko raslojavanje leksike svoje utemeljenje pronalazi u popunjavanju komunikativnih praznina, kojima se, različitom upotrebom u okviru različitih konteksta, mogu aktivirati željeni efekti u nastojanju da se dobije nijansa značenja koja je primjerena okolnostima u kojima nastaje.

\section{Sistem funkcionalno-stilskih kvalifikatora u leksikografiji}

U leksikografskim priručnicima daje se klasifikacija leksičkih jedinica čiji je status ustanovljen u leksičkom sistemu, gdje se nerijetko daju i odrednice, uglavnom kvalifikatori, kojima se definira njihova upotrebna strana u govoru i pisanju.

Katnić-Bakaršić (1999: 83) daje sljedeću klasifikaciju leksike s konotacijom:

a) emocionalno-ekspresivna leksika, b) leksika s određenom funkcionalno-stilskom markiranošću, c) profesionalizmi, d) neologizmi i arhaizmi, e) žargonizmi, argotizmi, f) dijalektizmi, egzotizmi.

Funkcionalno diferenciranje leksike izraženo je kroz sve više intenzivirano istraživanje i pročavanje jezika na komunikacijsko-funkcionalnom nivou, jer se svrha jezika postiže samo kad se upotrebljava, a govorna realizacija ima važnu ulogu jer se kroz nju oslikavaju verbalni mehanizmi u kojima se može nazrijeti ljudski faktor. Naprosto to je zato što taj ljudski faktor unosi svježinu u jezički izraz, oživljava riječ i u procesu komunikacije postaje važna sastavnica komunikacijske ekspeditivnosti. Stoga, funkcionalno diferenciranje leksike dobija svoj puni značaj u određivanju upravo onog značenja koje odražava određene komunikativne potrebe i ispunjava odgovarajuće okvire relevantne za sferu komunikacije. 
U procesu leksikografske obrade građe u Rječniku bosanskog jezika Dževada Jahića identificirani su stilski obilježeni leksemi koji pripadaju različitim funkcionalnim stilovima, odnosno imaju različitu izražajno-stilsku vrijednost, pa će se u navedenom korpusu naći i leksičke jedinice koje su određene sljedećim kvalifikatorima: afekt. ${ }^{4}$, arh..$^{5}$, augm. ${ }^{6}$, deprec. ${ }^{7}$, derog. ${ }^{8}$, dijal. ${ }^{9}$, ekspr. ${ }^{10}$, eufem. ${ }^{11}$, fam. ${ }^{12}$, gov. ${ }^{13}$, hip..$^{14}$, hist. ${ }^{15}$, indiv.${ }^{16}$, iron. ${ }^{17}$, knjir. ${ }^{18}$,

4 afektivno (Jahić 2010. I: 27).

5 arhaizam, arhaično. Mada taj sloj leksike inače nije ni teorijski ni praktički dovoljno definiran i mada u vezi s njim u leksikografiji ima mnogo lutanja, ovdje se u njegovom označavanju rukovodim osnovnom postavkom da su arhaizmi riječi ili značenja naporedni sa drugim riječima ili značenjima, pri čemu postoji svijest, koja nije samo intuitivna, o tome da je riječ u odnosu na naporedne riječi stara, odnosno da je "starinska" i da pripada najdubljem, temeljnom sloju leksičko-semantičkoga pamćenja izvornoga govornika. (Jahić 2010. I: 27).

6 augmentativ, augmentativno (Jahić 2010. I: 27).

7 deprecijativno; potcjenjivački; omalovažavajuće (Jahić 2010. I: 27).

8 derogativno; ponižavajuće (Jahić 2010. I: 27).

9 dijalekatski (Jahić 2010. I: 27).

10 ekspresivno. Odnosi se na riječ koja je markirana emocionalno ili asocijativno i koja kao takva iskače iz uobičajenoga, "ravnoga" načina govorenja, što znači da je ona po prirodi stvari vezana za govorni jezik, mada se može upotrijebiti i u pisanom jeziku. (Jahić 2010. RBJ I: 28)

11 eufemizam, eufemistički; blaže rečeno, ublaženo rečeno (Jahić 2010. I: 29).

12 familijarno, u odnosima veće bliskosti; familijarizam (Jahić 2010. I: 29).

${ }^{13}$ govorno. Riječ je uglavnom vezana za govornu upotrebu, a ne za pisanu (Jahić 2010. I: 29).

${ }^{14}$ hipokoristik, hipokoristično (Jahić 2010. I: 29).

15 historijski. Odnosi se na riječi iz prošlosti materijalne kulture, kojima se označavaju uglavnom različiti predmeti što već odavno nisu u upotrebi i umjesto kojih postoji samo riječ koja ih "pamti". (Jahić 2010. I: 29).

16 individualno. Označava riječ koja se na nivou jezičke kreacije javlja uglavnom samo kod jednog pisca. (Jahić 2010. I: 30).

17 ironično (Jahić 2010. I: 30).

${ }^{18}$ knjiški. Upućuje na riječ neraširenu u jezičkoj praksi, koja se nije dovoljno govorno potvrdila, koja zvuči oporo, neadaptirano, neprilagođeno (Jahić 2010. I: 31). 
meton.$^{19}$, neob..$^{20}$, netip..$^{21}$, pejor.$^{22}$, podr. ${ }^{23}$, poet..$^{24}$, povj. ${ }^{25}$, pren.${ }^{26}$, razg. ${ }^{27}$, reg. ${ }^{28}$, vulg. ${ }^{29}$, zast. $^{30} \mathrm{i} \check{z}$ arg. ${ }^{31}$

Ovakva funkcionalna i stilska klasifikacija leksičkog fonda bosanskog jezika u ovom Rječniku bosanskog jezika ukazuje na to da leksičke jedinice svojim oblikom i leksičkim značenjem stupaju u različite leksičko-semantičke odnose te da se njihov status može mijenjati tokom razvoja vokabulara. Autor je u metodološkoj razradi stilogeni fond leksema bosanskog jezika prilično široko postavio, pokazujući da ga čini složen i šarolik skup riječi kojima se može izraziti stilogenost.

Razmatrajući leksički sastav i leksikografski pristup u izradi ovog Rječnika, možemo kazati da je prilično reprezentativan i da odražava stilsku raznolikost bosanskog jezika. Razlog za to je što se tretirana leksika ekscerpirala iz različitih izvora: a) književnih i umjetničkih

19 metonimija, metonimijski (Jahić 2010. I: 32).

20 neobično (Jahić 2010. I: 32).

21 netipično. Odnosi se na riječi koje nisu svojstvene bosanskom standardnom jeziku ni jezičkim osjećaju izvornoga govornika, koje se neorganskim putem, najčešće preko medija ili političke javne riječi, neopravdano nameću tome jeziku (Jahić 2010. I: 33).

22 pejorativno (Jahić 2010. I: 33).

23 podrugljivo (Jahić 2010. I: 33).

24 poetski (Jahić 2010. I: 33).

25 povijest, povijesno. Upućuje na riječ vezana za historijska događanja, pojave, pojmove, za razliku od odrednice historijski (skrać. hist.), kojom se upućuje uglavnom na konkretne predmete iz prošlosti (Jahić 2010. I: 34).

${ }^{26}$ preneseno, preneseno značenje (Jahić 2010. I: 34).

27 razgovorni jezik, razgovorno; kolokvijalni jezik, kolokvijalno. Upućuje na najširu upotrebu u svakodnevnom jeziku i uopće na razgovorni, usmeni vid komunikacije jezikom. Sintagmatski i frazeološki izrazi, mada su oni u principu razgovorni, katkad se također obilježavaju ovom skraćenicom, ali se njome češće obilježavaju samo zasebne riječi i primjeri iz razgovornog jezika (Jahić 2010. I: 34).

28 regionalizam, regionalno. Upućuje na riječ raširenu i poznatu u nekoj od širih regija bosanskog jezika, dobrim dijelom uvjetovano i dijalekatskom bazom (Jahić 2010. I: 34).

29 vulgarizam, vulgarno (Jahić 2010. I: 36).

30 zastarjelo. Upućuje na riječ koja više nije u upotrebi, ali koja se na neki način pamti (Jahić 2010. I: 36).

31 žargon, žargonski. Odnosi se na riječi a) u najobaveznijoj i "komotnijoj” govornoj situaciji b) stručne termine uglavnom u govornoj upotrebi c) koje se upotrebljavaju u užim društvenim i generacijskim skupinama, donekle ograničeno i teritorijalno, u smislu urbanog centra, kakav je npr. slučaj sa sarajevskim žargonom (Jahić 2010. I: 37). 
tekstova, b) narodnih govora; c) folklornih tekstova - narodne pjesme, pripovijetke, priče, poslovice, izreke; d) različitih tekstova iz različitih naučnih oblasti - historije, etnologije i etnografije, književne kritike, lingvistike itd.; e) periodičnih izdanja - novine i časopisi; f) rječnika.

Stilske oznake u Rječniku su u službi karakterizacije funkcionalne upotrebljivosti leksike u jednom jeziku. U ovom radu nastojat ćemo utvrditi relevantne kriterije na osnovu kojih autor diferencira vremenski raslojene lekseme.

\section{Stilogeni aspekti vremenski raslojene leksike u Rječniku bosanskog jezika Dževada Jahića}

Kako je jezik dinamična kategorija, promjene do kojih dolazi u njegovoj strukturi najupečatljivije se odražavaju na leksičkom planu. Te su promjene odraz potreba s kojim se određeno društvo susreće u ekonomskom, socijalnom i političkom smislu, pa su novi pojmovi u jeziku nastali posredstvom novih prilika i fenomena, na što je ukazao i Kalajdžija (2013: 375), govoreći da leksika svjedoči o procesima razvoja društva, njegovim kulturnim i sociološkim prilikama u određenom vremenu.

Pojavom novih pojmova najčešće dolazi do gašenja, suzbijanja upotrebe određenih pojmova. Riječi koje su se prestale aktivno koristiti u govoru ne zaboravljaju se odmah. Takve riječi postaju dijelom rječnika pasivnog fonda, a daju se u rječnicima s fokusom na objašnjenja. $U$ Rječniku bosanskog jezika Dževada Jahića javljaju se četiri leksičko-semantičke kategorije kojima autor na različite načine tretira leksiku koja se iz ugla savremenog jezika doživljava kao pasivna ili makar neko njeno značenje smatra neaktivnim. Ćorić (1989: 122) navodi da "u načelu od zastarijevanja nije izuzet nijedan nivo jezičke strukture pa se, u skladu s tim, može govoriti o gramatičkim, leksičkim i semantičkim arhaizmima”. Predstavljena leksika u Rječniku s obzirom na vremensko raslojavanje klasificirana je na: arh. - arhaizme, hist. - historijsku leksi$\mathrm{ku}$, povj. - povijesnu leksiku i zast. - zastarjelu leksiku.

Korištenjem leksike koja je u savremenom smislu izašla iz upotrebe u tekstu do izražaja dolazi njena funkcionalna orijentacija, koja s 
obzirom na kontekst u kojem se koristi može imati različit stepen stilske ekspresivnosti.

\section{Ekscerpirana građa iz Rječnika bosanskog jezika (I tom)}

Primjeri koji su ovdje dati poredani su abecednim redom radi lakše preglednosti te su posebno razdvajani s obzirom na podjelu po kriteriju vremenske raslojenosti. Uz natuknice dati su primjeri upotrebe pojedine lekseme.

\section{Arhaizmi}

adžàmija (hadžàmija), u $z n$. neiskusan, nevičan, nevješt mlad čovjek, početnik [imam dragog adžamiju. - sevd.; mlado momče, adžamijo. nar. poet.] (Jahić 2010: 59)

àdžija, u zn. bol, gorčina, tuga [smrt je jedna adžija / tatarska je kandžija.] (Jahić 2010: 60)

àfedersun (àfedersum izg.), u zn. oprosti, izvini, pardon [afedersun, muderrise. Taljić] (Jahić 2010: 60)

àhar, u zn. štala, konjušnjica [i dolje u aharu zveči lanac našega ata. Humo] (Jahić 2010: 64)

àjluk (ájluk), u $z n$. mjesečna zarada; plaća, plata: općejez. [i dobar ti ajluk privezati. - nar. poet.; ajluk im bolji nego u našeg trgovca zarada. Dizdarević; bio sam odlučio da se odrečem ajluka. Selimović] (Jahić 2010: 66)

akrèba, u $z n$. 1. rodbina, svojta, rođaci b. rođak, srodnik [on mu dođe ko neka , ne znam su čiju stranu. - lok. (Jahić Rj.)] (Jahić 2010: 68)

älma, u zn. jabuka [almu sadih nasred At-mejdana. - sevd.] (Jahić 2010: 79)

ambréla (ambrèla), $u$ zn. kišobran [one dame, s onim ambrelama. Taljić] (Jahić 2010: 82)

arabàdžija, u zn. 1. kočijaš, kolar; furman 2. zanatlija koji izrađuje arabe [vrtiće joj se oko kuće arabadžije. Sijarić] (Jahić 2010: 99)

ásija (hásija), u zn. 1. onaj koji se osilio pa nikog ne priznaje; silnik, buntovnik, grješnik [ne valja bit' asija. Kadić] (Jahić 2010: 108) 
bôn, u $z n$. bolestan [plaho je ; kažu da je bon. Čolaković (Isaković Rj.); a pogled patnički ugasno, bon. Humo; jesi l se razgalio il si jošter bon? Latić] (Jahić 2010: 211)

bònluk (bònuk), $u z n$. obezbijeđenost svim sredstvima potrebnim za ugodan, lahgodan život; obilje, izobilje [ $i$ od bonluka samo za jedan akšam se strmeknule na fukarluk. Kasumović] (Jahić 2010: 212)

bòstan $^{32}, \mathrm{u} z n$. vrt, bašča [dva su cvijeta u bostanu rasla: / plavi zumbul $i$ zelena kada. - bal.; lijepa Zejna po bostanu šeće. - sevd.; šta radiš u ovom bostanu? - nar. prip.; djevojčica preskoči u bostan, odreza nekolike trske sladora. Bašagić (Nakaš); po bostanima pritjeruju brnače. Kikić] (Jahić 2010: 217)

bùčuk, u zn. polovina, polovica, pola [bila je, vala, mislim, po beš bučuk. Čolaković] (Jahić 2010: 246)

bùlbul, u zn. slavuj [zapjevala bulbul-ptica, misli zora je. - sevd.; bulbul pjeva na grančici. - sevd.; bulbul pjeva okolo Mostara. - sevd.; još kumrija i bulbula / milozvučni poj. Bašagić (Nakaš)] (Jahić 2010: 254)

cviker, u zn. naočari [kroz plavi cviker. Bašagić (Nakaš); ona sa cvikerom, profesorica književnosti. Sidran] (Jahić 2010: 294)

čalgìdžija (čàlgadžija), u zn. svirač, svirac, muzikant [čala, čala, čalgidžije mlade! - nar. poet. (Škaljić Rj.)] (Jahić 2010: 304)

čatlàisati, u $z n$. izluđivati od duševne ili fizičke tegobe; crći, crknuti, puknuti [crko, puko, čatlaisao, dok me ne vidio! (Škaljić Rj.) - nar. vjer., djevojka to izgovara kada čvara momku] (Jahić 2010: 312)

ćèfil (kèfil izv.), u zn. jamac; žirant [budi većil ako posla nejmaš, budi ako dužan n’jesi posl. (Ljubušak)] (Jahić 2010: 356)

Kao što vidimo, uz arhaizme koje smo ovdje naveli pokazana je njihova upotreba u različitim književnim vrstama, od narodnog stvaralaštva, preko književnih djela pa do naučnih izdanja. Prije svega, oni se koriste

32 Zanimljiva je sudbina ove riječi na bosanskohercegovačkom govornom području. Naime, njeno izvorno značenje je vrt. Ovo značenje na bosanskohercegovačkom govornom području gotovo da je potisnuto. Na zapadnohercegovačkom i centralnohercegovačkom terenu može značiti i dinja i lubenica. Već u istočnohercegovačkim govorima te ostalim dijalektima bosanskog jezika za ovu riječ uvriježeno je značenje lubenica. Ova riječ najčešće je govornicima bosanskog jezika poznata kroz frazemu "obrati (zelen) bostan, u značenju: nešto vrlo neprijatno, nepovoljno doživjeti; nastradati, nagrebusiti, nadrljati” (Jahić 2010: 217). 
za kreiranje koloritnosti dalekih vremena. Njihov leksički potencijal ogleda se u njihovoj interakciji s obzirom na kontekstne uvjete, pa pojedini autori oživljavajući stara značenja riječi unose u rečenicu ili tekst cjelovitiju ekspresivnu obojenost koja je potaknuta stilskom energijom koja je zaslužna za rekreiranje ambijenta i vremena starijih epoha. Pisci se često ovom leksičko-semantičkom grupom riječi koriste kao izražajnim sredstvima umjetničkog govora. U tom smislu, arhaična leksika često se koristi kao sredstvo za davanje melanholičnog, sjetnog, snuždenog tona. Takav ton na neki način nosi riječ bulbul u primjeru [zapjevala bulbul-ptica, misli zora je], gdje se može nazrijeti tužan pjev ptice s obzirom na to da djevojku udaju, bez njene volje, što vidimo iz stihova:

$$
\begin{aligned}
& \text { “Ustaj, Fato, ustaj, zlato, } \\
& \text { spremaj darove!" } \\
& \text { "Ja sam mlada i sirota, } \\
& \text { nemam darova." } \\
& \text { "Kad si mlada i sirota, } \\
& \text { što se udaješ?” } \\
& \text { "Udala me stara majka, } \\
& \text { nisam ni znala." }
\end{aligned}
$$

Upotrebom arhaizama u književnom djelu, osim što se evocira kulturno-historijski kontekst, mnogi pisci na taj način iskazuju i svoj stav spram vremena koji se javlja kao odrednica upotrebe tih leksema. Arhaizmi u tom smislu imaju važnu funkciju jer njihovom upotrebom književno djelo dobija otisak vremena, prenoseći na taj način historijsko-društvene i kulturne obrasce. Inače, arhaizmi su najčešće upotrijebljeni u takve stilističke svrhe i njih je u pravilu najviše. U tom smislu, spomenuli bismo primjere poput adžija, afedersum, ahar, ajluk, akreba, alma, ambrela, arabadžija, asija, bon, bonluk, bostan, bučuk, čalgidžija, ćefil. U književnim djelima u kojima se javljaju ove lekseme želi se dati do znanja da je riječ o vremenu koje je uslijedilo nakon osmanskih osvajanja ovih prostora. Dakle, u ovim djelima arhaizmi koji su upotrijebljeni su orijentalnog porijekla. Poznato je da su se orijentalizmi duboko adaptirali u jezički sistem bosanskog jezika jer su "podlijegali opštim unutarjezičkim zakonitostima raslojavajući se među sobom (bilo da su neki od njih vremenom zastarijevali - kao arhaizmi i istoricizmi 
- bilo da su postajali opšteprihvaćeni i bez semantičkih ekvivalenata, gubeći svoju markiranost po porijeklu” (Hadžiefendić 1984: 200). U vrijeme nastajanja primjera gore navedenih pisaca koji su u svoje djelo utkali orijentalizme, Osmansko carstvo je već palo. Naslućuje se da su pisci vrevu svakodnevnog života kojim su živjeli u novim društveno-političkim okolnostima lakše podnosili i pokušali razumjeti tu novu sadašnjost kroz prizmu historijskog ogledala. Čini se da je put ka razumijevanju te sadašnjosti poznavanje prošlosti, a taj put u književnim djelima popločan je starijim leksičkim slojem bosanskog jezika. I tu se vidi nit nostalgije za prošlim vremenima, koja je u vrijeme nastajanja ovih djela živjela u narodu, što nesumnjivo pisci dokazuju i potvrđuju svojim jezikom.

Arhaizmi također mogu poslužiti za iskazivanje podrugljivog, omalovažavajućeg tona kao što je slučaj s riječju adžamija: [imam dragog adžamiju. - sevd.; mlado momče, adžamijo. - nar. poet.] te riječju čatlaisati [crko, puko, čatlaisao, dok me ne vidio! (Škaljić Rj.)].

\section{Historicizmi}

äbadžija, u $z n$. 1. suknar, zanatlija koji izrađuje odjeću ili predmete od abe [valjalo je Jefti abadžiji odnijeti neku robu u dućan. Čolaković; ovo su uvakuflienje posvjedočila dva sarača, dva tabaka, četvorica čizmedžija, jedan abadžija i drugi. Kreševljaković] 2. trgovac koji prodaje izrađevine od abe (Jahić 2010: 55)

äbadžīnka, u $z n$. igla kojom se služi abadžija (Jahić 2010: 55)

àdžamkinja (àdžemkinja), u $z n$. sablja perzijske izrade; perzijanka; adžamovka, adžemovka (Jahić 2010: 60)

àkča, u $z n$. 1. novac u Turskoj carevini prvi put kovan za vladavine sultana Orhana [samo da njihove akče ostanu nedirnute u čekmedžetu. Selimović; imanje donosi oko sedam hiljada akči. Ibrišimović] 2. para, novčić; aspra, jaspra (Jahić 2010: 67)

altiluk, u $z n$. stari srebreni turski novac od šest groša (Jahić 2010: 80)

àmfora (àmfora), $\mathrm{u} z n$. antička prastara glinena posuda sa dvije drške (dva uha), u kojoj se držalo žito, vino, med i sl. (Jahić 2010: 83) 
antèrija, $\mathrm{u} z n$. vrsta gornje (muške i ženske) odjeće sa dugim rukavima [rezali mi bejaz anteriju. - sevd.; da ne nose zapetljane dimije, kao naše, nego anterije. Kulenović] (Jahić 2010: 92)

aràluk (haràluk), u $z n$. dograđena sporedna prostorija u starim bosanskim kućama, od dasaka ili nekoga drugog slabog materijala; predsoblje, mali hodnik [unesi mi to do a, a ja ću ga popet gore. - lok. (Hadžić Rj.); da je dobro odjeknulo cijelim ćoškom i aralukom. Osman-Aziz] (Jahić 2010: 100)

àrslan (u mn. arslani), u $z n$. vrsta novca [pored akče kolao je u prometu zlatni novac, zvani esedi groš ili arslani. Kreševljaković] (Jahić 2010: 106)

bàkam, ${ }^{33} \mathrm{u} z n$. rumenilo za lice, izrazito crvena boja koja se dobija iz drveta Caesalpinia sappan, porijeklom iz Indije (Jahić 2010: 133)

bàlista, u $z n$. ratna sprava, oruđe za izbacivanje teškoga kamenja kojim se gađalo pri opsadama utvrđenih gradova (Jahić 2010: 136)

baljèmez, u $z n$. starinski top velikoga kalibra i dometa [al udara more u obale, / al pucaju baljemez topovi? - nar. poet. (Škaljić Rj.)] (Jahić 2010: 138)

cvàncik, u $z n$. srebrni novac u austrougarsko doba u vrijednosti od 20 krajcera (Jahić 2010: 296)

čàdorbez, $\mathrm{u} z n$. vrsta debljega beza koji se najč. upotrebljavao za šatorska krila; botane [i čadorbez, znatno deblji i čvršći od domaćeg, a koji se uvozio iz Carigrada. Kreševljaković (Škaljić Rj.); nosili smo od čadorbe$z a$ iste takve košulje. Kikić] (Jahić 2010: 300)

čäka, u $z n$. svečana tvrda vojnička kapa u austrougarskoj vojsci (Jahić 2010: 302)

čàprazi, ukrasni gajtani sa krupnim dugmadima na čevkenima, libadama i sličnoj gornjoj muškoj odjeći [sve po prsim srmali čaprazi. - nar. poet. (Škaljić Rj.)] (Jahić 2010: 306)

čèlēnka, $\mathrm{u} z n$. vrsta perjanice načinjene od zlata ili srebra u obliku spojenih pera, katkad ukrašena i dragim kamenjem (stavljala se na kalpak ili saruk sa prednje strane) [djeverovski kalpak i čelenka. - bal.; ostala

33 Ova riječ ima i svoje arhaično značenje: ruž za usne; karmin [kna i surma su se uvozili a bjelilo, bakam i boja za kosu bili su domaći proizvodi. Kreševljaković; a usne joj poput trešnje s pramaljetja crvene se, sjaju od bakama. Čolaković] (Jahić 2010: 133). 
su samo djeca da mu vide na kapi čelenku. Sijarić; mermer si cjelivala sabah-poljupcem meni nad glavom čelenkom vihornom. Azizov] (Jahić 2010: 317)

ćèfenak (ćèpenak), u $z n$. krilo, kanat starinskoga dućana koji se otvara i zatvara služeći mjesto vrata [na ćefenke noge naslonila. - nar. poet.; a kamo li ko je imao koju paru pa otvori ćefenak. Mulabdić; nestade i ćefenaka. Dizdarević; i tresu se ćefenci, žene prolijeću iz kuće u kuću. Dizdarević; zatim podigo ćefenak i spustio kapke. Čolaković; išao pognute glave pored ćefenaka. Selimović; ubrzo je i poslove s ćefencima prepusito momcima. Taljić] (Jahić 2010: 356)

cùrdija, $\mathrm{u} z n$. vrsta gornje kratke i duge haljine postavljene krznom, čije je lice najč. od kadife ili čohe [muška , ženska ; pa obukla čičekli ćurdiju. - nar. poet. (Škaljić Rj.)] (Jahić 2010: 371)

Kad je u pitanju upotreba historicizama, oni stoje u suprotnosti sa arhaizmima. Samardžija (2001: 29) navodi: "Leksemi koji su iz aktivnog u pasivni leksik prešli djelovanjem izvanjezičnih čimbenika nazivamo historizmima." Imajući u vidu ovu činjenicu, jasno je da arhaizmi kao fenomen svoje postojanje temelje na faktorima koji su lingvističke naravi. Historicizmima se označava nestajanje stvarnosti i pojmova koji su bili aktuelni u određenoj historijskoj epohi, što uvjetuje da ono što je njima bilo označeno pređe iz aktivne u pasivnu leksiku, pa je samim tim ograničena upotreba takve riječi. Važno je kazati da se te leksičke jedinice i dalje koriste, ali s određenim funkcionalnim ograničenjem, najčešće u onim knjigama koje se tiču opisivanja nekog perioda u historijskom razvoju ili pak u književnim djelima kada se pisci koriste takvom leksikom kako bi rekreirali određeno društveno-političko ili socijalno-ekonomsko uređenje i sl.

L. Zgusta (1991: 171) u vezi s historicizmima konstatuje "da se ne bojim terminoloških inovacija, nazvao bih ih riječima vezanim za vrijeme”. Naime, vremenski kriterij je presudan da neku leksemu proglasimo historicizmom. Ova Zgustina postavka potpomognuta Samardžijom definicijom historicizma osvjetljava kriterij za razlikovanje historicizma i arhaizma. S obzirom na to da se vrijeme u kojem neka riječ postaje arhaizmom praktično ne može procijeniti niti "uhvatiti", jer je uzrokovano unutarjezičkim razlozima, onda se historicizmi bez problema 
mogu datirati, jer su povezani sa promjenama u okolnom svijetu. To znači da historicizmi nisu zastarjele riječi, već su to riječi koje označavaju pojmove koji više ne postoje ili su zastarjeli.

No kad je riječ o funkcijama historicizama, njima se u književnosti i općenito u publicističkoj djelatnosti autori koriste kao tehnikom koja pomaže istinitom slikanju određenog perioda, odnosno materijalne kulture određenog vremenskog perioda u razvoju nekog podneblja. Tako upotrijebljene, one djeluju kao svjedočanstvo o postojanju zanimanja, novčanih jedinica, poreza, odjevnih i drugih predmeta.

Historicizmi koje smo ovdje naveli također služe za rekreiranje vremenske epohe u okviru Osmanskoga carstva. Tako smo nešto više iz toga perioda saznali o odjevnim predmetima - anterija, čaka, čaprazi, čelenka, ćurdija, o vrstama oružja - balista, baljemez, o novcu koji se koristio u to vrijeme - akča, altiluk, arslani, cvancik, o posebnim odajama unutar kućnog uređenja - araluk, o predmetima koji su se koristili u posebne svrhe - čadorbez, ćefenak, o sredstvu koje su žene koristile za uljepšavanje - bakam, te zanimanjima - abadžija, kao i sredstvima kojima su se koristili u obavljanju neke djelatnosti - abadžinka. Upotreba navedenih riječi koje su ekscerpirane iz Rječnika ovjerena je kroz primjere u književnim djelima, što im obezbjeđuje stilističku vrijednost.

\section{Povijesna leksika}

àdžami-òglan (àdžemi-òglan $i z v$.), u $z n$. dječaci sa osvojenih turskih područja odvođeni u Carigrad na školovanje i odgoj [kad se uzme da mu (Sokoloviću) je bilo petnaest godina kad je kao adžami-oglan došao u carski dvor. (Škaljić Rj.)] (Jahić 2010: 60)

àdžamskī (àdžemskī), u $z n$. koji se odnosi i na bilo koju drugu azijsku muslimansku zemlju van granica Osmanskog carstva (Jahić 2010: 60)

àga, u $z n$. vlasnik zemlje (u Turskoj carevini) koju su obrađivali drugi, uglavnom hrišćanski kmetovi (Jahić 2010: 61)

ajálet, u $z n$. oblast, pokrajina, provincija pod upravom valije [Bosna je za turske uprave najprije bila ajalet, a 1865. godine postala je vilajet. (Škaljić Rj.)] (Jahić 2010: 65) 
akìndžija, u zn. pripadnik odreda jurišnih konjanika, vrsta vojske u Bosni za vrijeme Osmanskog carstva [akindži - vrsta bosanskohercegovačke vojske, takođe konjaništva. Bašagić (Nakaš)] (Jahić 2010: 67)

bäšaga, u $z n$. glavni aga, starješina agā, aginski prvak (Jahić 2010: 144) bašèskija, u $z n$. stari, isluženi janjičar; janjičarski veteran [kahveni pribor kahvedžije bašeskije Uzun Mustafage, sina Hasanova, iz Bali zade mahale, procijenjen je 1784. godine na 1680 akči. Kreševljaković; ja, siromah, tvoja bašeskija. Latić] (Jahić 2010: 145)

bèglerbeg, $\mathrm{u} z n$. vrhovni vojni i civilni zapovjednik neke oblasti ili pokrajine u sastavu Turske carevine (Jahić 2010: 151)

boljšèvìk, u $z n$. 1. prvobitno član većinske Socijaldemokratske radničke partije od 1903. godine; većinaš bukv.; supr.: menjševik; manjinaš bukv. 2. pristalica boljševizma u Rusiji nakon Oktobarske revolucije, "sudionik", izvršilac represivne državne politike Komunističke partije Sovjetskog Saveza (Jahić 2010: 210)

bosànčica, $u z n$. ćirilica sa svojim posebnim grafijsko-paleografskim odlikama koja se upotrebljavala u Bosni od srednjeg vijeka do novijeg vremena; bosanica, bosanska azbuka, zapadna (bosanska) ćirilica; zapadna ćirilica; bosančica je, filološki preciznije rečeno, zapadna brzopisna ćirilica. Filipović N. (Isaković Rj.)] (Jahić 2010: 215)

cionìzam, $\mathrm{u} z n$. učenje, nacionalni pokret Jevreja za uspostavljanje jevrejske države u Palestini (Jahić 2010: 281)

cüksfïrer, u $z n$. oficirski čin u austrougarskoj vojsci [ $i$ dođe, dragi si moj, jednoć cuksfirer. Dizdarević; jedan cuksfirer nam održa govor. Sušić] (Jahić 2010: 295)

čeràhor, $u z n$. fizički radnik koji pod nadzorom majstora radi na teškim poslovima zidanja i popravljanja gradova, utvrđenja, mostova i sl.; vrsta kulučara [čerahori su gradili i popravljali gradove. Kreševljaković (Isaković Rj.)] (Jahić 2010: 320)

čifčija, seljak bezemljaš; kmet na aginskoj ili begovskoj zemlji, na čifluku [spremio sam njega u čifčije. - nar. poet.; čifčija si bio u turaka. - nar. poet.] (Jahić 2010: 327)

Za razliku od historicizama kojima se, kako se može vidjeti, označavaju nekadašnja zanimanja, novčane jedinice, porezi, odjevni i drugi 
predmeti, povijesnom leksikom se označavaju historijski događaji, pojave, pojmovi, nekadašnje titule i zvanja. Udio ove leksike u analiziranoj građi je manji u odnosu na arhaizme i historicizme. To je i razumljivo, s obzirom na to da je spektar fenomena koji su obuhvaćeni ovim terminom u stvarnosti daleko manji od prethodna dva koja smo obradili.

Kako vidimo iz ekscerpirane građe, i ovi primjeri su potvrđeni u književnoj produkciji. Stilska funkcija i ovog sloja pasivne leksike nije ništa drugo doli izražavanje historijske izvornosti nekog događaja. Korištenje realnih pojmova iz nekadašnje ere bitisanja pomaže piscima da stvore što pouzdaniju pozadinu radnje koja se odvija. Upotrebom te leksike pisci nas direktno povezuju s kulturom i historijom etnosa. U vezi sa ovim slojem leksike, najzastupljeniji su termini iz okvira zvanja i titula osmanskoga perioda vladavine: aga, bašaga, beglerbeg, kao i termini iz društvenog položaja u ondašnje vrijeme: adžami-oglan, bašeskija, boljševik, čerahor, čifičija. Također, u analiziranom Rječniku pronašli smo i leksiku koja nije u vezi sa vremenom vladavine Osmanskog carstva. Takvom leksikom imenuju se društveno-politička uvjerenja i nastojanja - cionizam, te leksema cuksfirer sa značenjem oficirskog čina za vrijeme austrougarske vladavine.

\section{Zastarjela leksika}

balàban, u $z n$. a. medvjed koji se voda po vašarima i pokazuje svijetu b. cirkuski medvjed (Jahić 2010: 135)

blûz, u $z n$. oblik crnačkih američkih pjesama (Jahić 2010: 194)

bôd, u $z n$. predmet kojim se bode a. bodež, nož b. bajonet, bajoneta; boda (Jahić 2010: 197)

bôjnik, u $z n$. borac, ratnik, bojovnik (Jahić 2010: 205)

bölovānje, u $z n$. bolest [poslije kratkog mu bolovanja. Ćatić (Nakaš)] (Jahić 2010: 199)

bòljetica (boljètica), u zn. bolest, boljka [ljuta boljetica. Hadžić O. N. (Nakaš); teška boljetica. Mulabdić (Nakaš)] (Jahić 2010: 210)

bùntāš, u $z n$. buntovnik (Jahić 2010: 257) 
cäjg, u $z n$. jeftina tkanina od pamuka od koje se kroje pantalone i odijela (Jahić 2010: 264)

cikáda, u $z n$. cvrčak (Jahić 2010: 277)

U leksikologiji se pravi razlika između zastarjelih riječi i arhaizama, ali je ta granica neznatna jer prema mišljenju Radović-Tešić (1982: 261) "arhaizam jeste zastarela reč, ali nije svaka zastarela reč arhaizam. Arhaizam je znači uži pojam od zastarele reči." Ovih leksičkih jedinica je najmanje, što je i razumljivo jer su ovo riječi koje su sasvim nepoznate prosječnom govorniku bosanskog književnog jezika, a njihovo razumijevanje uvjetovano je dopunom odgovarajućih podataka. Za razliku od prethodna tri sloja vremenski raslojene leksike, ovaj sloj leksike najčešće je potpuno iščezao iz pamćenja. Radović-Tešić (1982: 261) smatra da je razlog takvog njihovog statusa u jeziku uzrokovan time što su u vrijeme kada su ih pisci upotrebljavali one bile stilske neutralne, što za posljedicu ima da se one u savremeni jezik ne mogu vratiti kao lekseme sa izrazitom stilističkom vrijednošću. To potvrđuju i ekscerpirani primjeri, među kojima se, istini za volju, sporadično navode i književna djela u kojima su pronađene takve lekseme, ali one nemaju nikakav stilistički naboj.

\section{Zaključak}

$\mathrm{Na}$ početku stilističke analize leksičkog fonda u kontekstu vremenske raslojenosti leksema u Rječniku bosanskog jezika Dževada Jahića bazirali smo se na utjecaj razgovornog jezika na funkcionalno-stilsko raslojavanje, gdje smo pozivajući se na ranija istraživanja utvrdili da razgovorni jezik ima snažan potencijal na generiranje funkcionalno-stilskih vrijednosti leksike. Tako smo preko razgovornog jezika, koji ima izrazit utjecaj na standardni jezik, došli do centralnog pojma u stilistici - konotativnost. Konotativnost nadalje podrazumijeva posebnu izražajnost koja je potaknuta pristranošću, asocijativnošću, ekspresivnošću. S obzirom na to da se konotativnost može vezati za pojedinu riječ, nadalje smo ponešto kazali o njenim osobinama, te u vezi s tim govorili o funkcionalno-stilskoj diferencijaciji leksike unutar književnog jezika. U radu je posebno tretirano pitanje vremenske raslojenosti leksičke građe 
u Rječniku bosanskog jezika autora Dževada Jahića, gdje smo na pojedinim primjerima iz ekscerpirane građe pokazali na koji način je $s$ vremenskog aspekta predstavljena obrađena leksika.

$\mathrm{Na}$ temelju provedene analize, a na referentnom broju primjera, došli smo do zaključka da su lekseme koje smo uvrstili i pojedinačno obradili kao arhaizme, historicizme i povijesnu leksiku vezane uglavnom za doba osmanske vladavine. Primjerima iz književnih djela ta leksika je oživljena, a specifična upotreba te leksike udahnula joj je novi život, dajući joj stilsku vrijednost pri čemu se na taj način kreira određena kulturno-društvena pozadina, ambijent, ozračje. Stoga je stilska vrijednost te leksike ovjerena neophodnošću upotrebe u slučaju da želimo stvoriti sliku društveno-političkog uređenja i nacionalno-historijskog ukusa. U tom kontekstu posljednji sloj pasivne leksike, u Rječniku nazvan zastarjelom leksikom, beznačajan je u smislu davanja posebnih stilističkih vrijednosti.

Općenit zaključak koji možemo donijeti na osnovu primjera koje smo s nekim od kvalifikatora za pasivnu leksiku pronašli u Rječniku bosanskog jezika (tom I) jeste da je orijentalna leksika u tom sloju najzastupljenija.

$\mathrm{Na}$ kraju, korištenjem pasivne leksike u književnim djelima pisci su toj leksici dali na stilskoj vrijednosti, pa takva leksika mora naći svoje mjesto u rječniku, ako ne iz normativnih razloga, onda svakako zbog svoga stilskog potencijala. Pojavljivanje i opisivanje takve leksike u rječnicima stalo je na put njenoj konačnoj zastarjelosti.

\section{Izvor}

Jahić, Dževad (2010): Rječnik bosanskog jezika, I tom.

\section{Literatura}

Bugarski, Ranko (2006): Žargon, Drugo, prerađeno i prošireno izdanje, Biblioteka XX vek, Beograd.

Ćorić, Božo (1989): “O jednom tipu leksičkih arhaizama u srpskohrvatskom jeziku”, Fluminensia: časopis za filološka istraživanja 1 (1), Odsjek za kroatistiku Filozofskoga fakulteta u Rijeci, Rijeka, 122-126. 
Durbaba, Olivera M. (2015): “O nestandardnoj leksici u leksikografskim izvorima”, Anali Filološkog fakulteta 27, Filološki fakultet Univerziteta u Beogradu, Beograd, 211-223.

Hadžiefendić, Remzija (1984): “Turcizmi u funkciji imenovanja likova u Dervišu i smrti i Na Drini ćuprija”, Književni jezik 13/4, Institut za jezik i književnost u Sarajevu, Sarajevo, 199-217.

Ivić, Milka (1990): O jeziku Vukovom i vukovskom, Književna zajednica Novog Sada, Novi Sad.

Kalajdžija, Alen (2013): “Terminologija oružja u bošnjačkoj epici”, Znakovi vremena XVI (61/62), Sarajevo, 339-359.

Katnić-Bakaršić, Marina (1999): Lingvistička stilistika, Open Society Institute, Budapest.

Klajn, Ivan (1998): “O kriterijumima za semantičko normiranje reči”, Naš jezik XXXII/3-4, 134-147.

Kövecses, Zoltán (2005): Metaphor in Culture, Universality and Variation, Cambridge University Press (CUP), University of Cambridge, Cambridge.

Lakoff, George (1987): Women, fire, and dangerous things: What categories reveal about the mind, University of Chicago Press, Chicago.

Menac, Antica (1998): “Pitanja stilističke kvalifikacije u općim i frazeološkim rječnicima”, Filologija 30-31, Hrvatska akademija znanosti i umjetnosti, Zagreb, 261-266.

Muratagić-Tuna, Hasnija (1992): Jezik i stil Ćamila Sijarića, Filozofski fakultet - ITP “Damad”, Priština - Novi Pazar.

Radović-Tešić, Milica (1982): "Arhaizmi i njihova obrada u rečniku SANU", Poseban otisak iz zbornika Leksikografija i leksikologija, Institut za srpski jezik SANU, Beograd, 257-262.

Ristić, Stana (1995): "Neki aspekti normiranja u leksikografiji”, Naučni sastanak slavista u Vukove dane 24/1, Filološki fakultet Univerziteta u Beogradu, Beograd, 233-240.

Ristić, Stana (1997): "Neke karakteristike ekspresiva u delima Stevana Sremca”, u: Književno delo Stevana Sremca - novo čitanje, Zbornik referata sa 
naučne konferencije održane u Nišu 15. i 16. novembra 1996, Centar za naučna istraživanja SANU i Univerziteta, Niš, str. 43-56.

Ristić, Stana (2002): “Ekspresivna leksika u deskriptivnom rječniku”, u: Deskriptivna leksikografija standardnog jezika i njene teorijske osnove, Zbornik sa Međunarodnog naučnog skupa o leksikografiji i leksikologiji, Matica srpska, Novi Sad, str. 89-102.

Ristić, Stana (2006): Raslojenost leksike srpskoga jezika i leksička norma, Institut za srpski jezik SANU, Beograd.

Samardžija, Marko (2001): Hrvatski jezik 4, Udžbenik za 4. razred gimnazije, Školska knjiga, Zagreb.

Vinogradov, Viktor (1971): Stilistika; teorija poetskoga jezika; poetika, prijevod P. Lazarević, T. Šeremet i M. Milinković, Zavod za izdavanje udžbenika, Sarajevo.

Vuković, Novo (2000): Putevi stilističke ideje, Univerzitet Crne Gore u Nikšiću, Podgorica.

Zgusta, Ladislav (1991): Priručnik leksikografije, Svjetlost, Sarajevo. 


\title{
Stylogenicity of time-layered lexicon in The Dictionary of the Bosnian Language by Dževad Jahić
}

\begin{abstract}
The paper initially discusses some theoretical aspects of functional-stylistic stratification of vocabulary, with an emphasis on spoken language and its impact on standard language in terms of generating new stylistic values. Spoken language belongs to the colloquial style, so given its great potential in creating the connotative meaning of words, its boundaries are not clearly set, and in the communicative act almost every word can undergo semantic modification, resulting in special semantic or stylistic nuances. Stylistic nuance of vocabulary finds its foundation in filling communicative gaps, which, through different use in different contexts, can activate the desired effects in an effort to obtain a nuance of meaning that is appropriate to the circumstances in which it occurs. Furthermore, the paper pays special attention to the stylogenic values of time-layered vocabulary, ie passive vocabulary in the Dictionary of the Bosnian Language by Dževad Jahić. By using vocabulary that has gone out of use in the text in the modern sense, its functional orientation comes to the fore, which, given the context in which it is used, can have different degrees of stylistic expressiveness. Thus, the stylistic character of lexemes with the qualifier of archaism, historicism, historical and obsolete lexicon is considered, taking into account the examples excerpted from the material given with each entry. After conducted analysis, the stylistic function of passive vocabulary is nothing but the expression of the historical originality of an event. Using terms from the former era of existence helps writers to get their literary work on a truer and more convincing painting of a certain period, thus transmitting historical, social and cultural patterns and material culture of a region.
\end{abstract}

Keywords: linguistic stratification, stylogeny, colloquial style, connotation, archaism, historicism, historical vocabulary, outdated vocabulary

\section{Izjava autora o nepostojanju sukoba interesa i poštivanju općih etičkih kodeksa:}

Autor potvrđuje da ne postoji nikakav stvarni ili mogući sukob interesa vezan za ovaj tekst te da je tekst napisan u skladu s etičkim kodeksima prema preporukama COPE (Committee of Publishing Ethics). 